164(a) RHR

Draft

Published in Timothy S. Shah and Allen D. Hertzke, eds., Christianity and Freedom: Volume 1: Historical Perspectives (Cambridge: Cambridge University Press, 2016), 210-234

\title{
Calvinist Contributions to Freedom in Early Modern Europe
}

John Witte, Jr.

\begin{abstract}
This chapter sketches the development of rights talk in those parts of the Western tradition inspired by the teachings of the Genevan Reformer, John Calvin (1509-1564). Building in part on classical and Christian prototypes, Calvin developed arresting new teachings on authority and liberty, duties and rights, and church and state that have had an enduring influence on Protestant lands. Calvin's original teachings were periodically challenged by major crises in the West -- the French Wars of Religion, the Dutch Revolt, the English Revolution, American colonization and the American Revolution. In each such crisis moment, a major Calvinist figure emerged -- Theodore Beza, Johannes Althusius, John Milton, John Winthrop, John Adams, and others -- who modernized Calvin's teachings and converted them into dramatic new legal and political reforms. This rendered early modern Calvinism one of the driving engines of Western constitutionalism. A number of our bedrock Western understandings of civil and political rights, social and confessional pluralism, federalism and social contract, and more owe a great deal to Calvinist theological and political reforms. This chapter distills the author's book length treatment of the subject, The Reformation of Rights: Law, Religion, and Human Rights in Early Modern Calvinism (Cambridge University Press, 2007).
\end{abstract}

Keywords: John Calvin; Geneva; Theodore Beza; St. Bartholomew's Day Massacre; Marian Exiles; Magdeburg Confession; Christopher Goodman; Dutch Revolt; Johannes Althusius; John Milton; Levellers; English Revolution; Puritan New England; Nathaniel Ward; Body of Liberties; doctrine of sin; checks and balances; separation of powers; written constitutions

\section{Introduction}

In an important new book on The Hebrew Republic: Jewish Sources and the Transformation of European Political Thought, Harvard historian Eric Nelson sharply criticizes the "standard narrative" of early modern political history. The standard 
narrative describes this as an era devoted to the separation of religion and politics and to the construction of a secular order built on "pagan classical" learning, Renaissance humanism, and early Enlightenment liberalism. This is largely a "myth," Nelson argues. The reality is that the early modern era saw "the full fervor of the Reformation unleashed," with "political theology" made very much part of "the mainstream of European intellectual life." It was in this overtly religious milieu that the West built many of its cardinal institutions of confederation, human rights, constitutional order, popular sovereignty, democratic politics, and the rule of law. Protestant theological jurisprudence, Catholic political theory and canon law, and Jewish biblical thought, says Nelson, were just as critical to the modern Western political project as the purportedly secular theories of Aristotle, Machiavelli, or Hobbes. ${ }^{1}$

Several other chapters in this volume analyze the critical religious sources and dimensions of law, politics, and freedom before, during, and after the Enlightenment. In this chapter, I focus on the early modern theories and institutions inspired by the teachings of the Genevan Protestant Reformer, John Calvin (1509-1564). ${ }^{2}$ Building in part on classical and Christian prototypes, and drawing on his legal and theological training, Calvin developed arresting new teachings on authority and liberty, duties and rights, and church and state that have had an enduring influence on Protestant lands. Calvin's original teachings were periodically challenged by major crises in the next two centuries - the Marian persecutions of Protestants in England and Scotland, the St. Bartholomew's Day Massacre and wars of religion in France, the Dutch Revolt against Spanish tyranny, the English Revolution and Civil War, the American Revolution, and more. In each such crisis moment, a major Calvinist figure emerged - John Knox, Theodore Beza, Johannes Althusius, John Milton, and others - -who reformed Calvin's teachings and converted them into dramatic new legal, political, and constitutional reforms. This rendered early modern Calvinism one of the driving engines of Western constitutionalism. This is the main argument of this chapter, though I leave the American part of the story to David Little's chapter herein.

\section{John Calvin and Geneva}

Early Views. John Calvin set out some of his enduring teachings on law, authority, and liberty already in his 1536 Institutes of the Christian Religion. In this early

\footnotetext{
${ }^{1}$ Eric Nelson, The Hebrew Republic: Jewish Sources and the Transformation of European Political Thought (Cambridge: Harvard University Press, 2010), 2-3.

2 This chapter is drawn in part from my work on early modern Calvinism. See John Witte, Jr., The Reformation of Rights: Law, Religion, and Human Rights in Early Modern Calvinism (Cambridge: Cambridge University Press, 2007) (hereafter cited as RR), and Robert M. Kingdon and John Witte, Jr., Sex, Marriage, and Family in John Calvin's Geneva, 2 vols. (Grand Rapids: Wm. B. Eerdmans Publishing Co., 2005-2014) (hereafter cited as SMF). These volumes include detailed sources that are not duplicated herein.
} 
masterwork, Calvin echoed the Protestant call for Christian liberty made famous by Martin Luther a generation before - - liberty of the individual conscience from Catholic canon laws and clerical controls, liberty of political officials from ecclesiastical power and privilege, liberty of the local clergy from central papal rule, liberty of the young Protestant churches from oppression by church and state alike in violation of the people's rights and liberties. ${ }^{3}$

Calvin called for a basic separation of the offices and operations of church and state. The church holds the spiritual power of the Word. Ministers are to preach the Word and administer the sacraments. Doctors are to catechize the young and to educate the parishioners. Elders are to maintain discipline and order and adjudicate disputes. Deacons are to control the church's finances and to coordinate its care for the poor and needy. Each of these church officials is to be elected to his office by communicant members of the congregation. Each is subject to the limitation of his own office, and the supervision of his fellow officers. ${ }^{4}$

The state holds the legal power of the sword. State officials are God's "viceregents" in this earthly life. They are vested with God's authority and majesty, and are "called" to an office that is "the most sacred and by far the most honorable of all callings in the whole life of mortal men." They are commanded to embrace and exemplify clemency, integrity, honesty, mercy, humanity, and other Godly virtues. Political rulers must govern by written positive laws, not by personal fiat. Their laws must encompass the biblical principles of love of God and neighbor, but they must not embrace biblical laws per se. Instead, natural law and "equity alone must be the goal and rule and limit of all laws." Through written, equitable laws, political rulers must serve to promote peace and order in the earthly kingdom, to punish crime and civil wrongdoing, to protect persons in their lives and properties, "to ensure that men may carry on blameless intercourse among themselves" in the spirit of "civil righteousness."

These God-given duties and limits define not only the political office but also the political liberty of Christian believers. Political liberty and political authority "are constituted together," said Calvin in these early years. The political liberty of believers, he said, is not so much a subjective right as a function of the political office. When political officials respect the duties and limits of their office, believers enjoy ample

\footnotetext{
${ }^{3}$ For an exploration of the sources in support of this argument, see John Witte, Jr., Law and Protestantism: The Legal Teachings of the Lutheran Reformation (Cambridge: Cambridge University Press, 2002), 1-5, 53-69.

${ }^{4}$ G. Baum, et al., eds., "Ecclesiastical Ordinances (1541)," in loannis Calvini opera quae supersunt omnia, 59 vols. (Brunswick: C.A. Schwetschke, 1863-1900),10/1:15-30 (hereafter cited as CO). Since $\mathrm{CO}$ has variant pagination in later editions, and there are sundry translations of these individual texts, I am using the shorthand citations to Calvin's letters and commentaries.

5 John Calvin, Institution of the Christian Religion [1536], trans. Ford Lewis Battles (Atlanta: John Knox Press, 1975), 1.33, 6.33-49 (hereafter cited as Institutes (1536)).
} 
political liberty to give "public manifestation of their faith." When political officials betray their office, however, through negligence, injustice, overreaching, or outright tyranny, the political liberty of the believer is abridged or even destroyed. As a consequence, said Calvin, "those who desire that every individual should preserve his rights, and that all men may live free from injury, must defend the political order to the utmost of their ability."6

Calvin insisted that private individuals have a Godly duty to obey tyrannical political officials up to the limits of Christian conscience. "The powers that be are ordained by God," and the Bible repeatedly enjoins our obedience to them (Rom. 13:17, Titus 3:1, 1 Pet. 2:13). These obligations of obedience continue even when these authorities become abusive and arbitrary, Calvin insisted. This is particularly true in the political sphere, which provides order and stability for individuals and groups to flourish. Some political order is better than no order at all, and private disobedience usually brings greater disorder. Some justice and equity prevail even in the worst tyrannies, and even that is jeopardized when individuals take the law into their own hands. Sometimes tyrannies are God's test of our faith or punishment for our sin, and we insult God further by resisting his instruments. Individuals must thus obey and endure patiently and prayerfully, and leave vengeance and retribution to God. ${ }^{7}$

But to honor earthly authorities cannot be to dishonor God, Calvin continued, for the Bible says: "We must obey God rather than men" (Acts 5:29). When earthly authorities command people to disobey God or the Bible, the people not only may disobey - they must disobey. Our "obedience is never to lead us away from obedience to Him, to whose will the desires of all kings ought to be subject, to whose decrees their commands ought to yield," Calvin wrote. "If they command anything against Him, let it go unesteemed." For to love and honor God is the first and greatest commandment. All authorities who betray their office to the detriment or defamation of God forfeit their office and are reduced to private persons. They are no longer authorities but mere "brigands" and "criminals." "Dictatorships and unjust authorities are not governments ordained by God," "Those who practice blasphemous tyranny" are no longer "God's ministers." 8

But how should the people disobey? Calvin knew enough about the insurrection triggered by the Anabaptist radicals of his day and had read enough in classical history about the dangers of simply unleashing the crowd against tyrants. So, he sought a

\footnotetext{
${ }^{6}$ Ibid., 6.54; Commentary on Romans 13:10.

7 Institutes (1536), 6.54-55; Comm. Rom. 12:17-19; 13:1-10. See also Commentary on Timothy, Titus, Philemon 3:1; Commentary on 1 Peter 2:13; Commentary on the Harmony of the Gospels Matthew. 5:3841, Luke 6:29-30; Commentary on 1 Corinthians 7:14-15; Sermons on Deuteronomy 5:16; Commentary on Harmony of the Law, Deut. 5:16.

${ }^{8}$ Institutes (1536) 6.56; Comm. Rom. 13:1-7; Commentary on Acts 5:29, 7:17.
} 
more structured and constructive response led by state and church authorities. No political regime is governed by "one person alone," Calvin argued. Even monarchs have a whole coterie of lower officials - counselors, judges, chancellors, and others charged with implementation of the law. Moreover, many communities have "magistrates of the people, appointed to restrain the willfulness of kings," whether the ephors of ancient Greece or the elected parliamentarians of our day. These lower elected officials must protect the people through active resistance, even revolt, if higher magistrates become abusive or tyrannical in violation of God's authority and law. ${ }^{9}$

Church leaders, in turn, must preach and prophesy loudly against the injustice of tyranny and petition tyrannical magistrates to repent of their abuse, to return to their political duties, and to restore the political freedom of all peaceable persons. Calvin opened his 1536 edition of the Institutes with precisely such a petition to King Francis I, on behalf of the persecuted Protestants in France. In his dedicatory epistle to Francis, he stated that, as a believer, he was compelled to "defend the church against [political] furies," to "embrace the common cause of all believers." Against "overbearing tyranny," Calvin later put it, a Christian must "venture boldly to groan for freedom."10

Later Views. In his later writings, Calvin worked out a fuller account of individual subjective rights and a fuller theory of church and state. Given his early legal training in the ius commune where subjective rights talk was commonplace, Calvin comfortably used the Latin term ius in a subjective sense, and had indeed done so a few times in his early writings in the 1530s. But in these early writings, his accent was on subjective liberties (libertates) from tyranny and oppression, not on subjective rights (iura) to actions, goods, and services that could be claimed against the state and other institutions and individuals as well. In his later writings in the 1540s and 1550s, Calvin emphasized more fully the need to protect both the subjective "rights" (iura, droits) of individuals in addition to their "liberties" or "freedoms" (libertates, libertés). Sometimes, he called generically for protection of "the common rights of mankind" (iura commune hominum), the "natural rights" (iura naturali) of persons, the "rights of a common nature," (communis naturae iura), or the "the equal rights and liberties" (pari iura et libertates) of all. ${ }^{11}$ Usually, he referenced more specific rights that deserved recognition and protection. He spoke, for example, about the "rights of Christian liberty," the "rights of citizenship" in the Kingdom of God or in heavenly Jerusalem, and, one of his favorite expressions, the "right of adoption" that Christians enjoy as new sons and daughters of God and brothers and sisters in Christ. He referenced "the right to inhabit," "the right to dwell in," and "the right and privilege to claim the territory" that Yahweh gave to the chosen people of Israel. He mentioned "Paul's rights of Roman citizenship."

\footnotetext{
9 Institutes (1536), 6.55.

$10 \mathrm{lbid}$., Dedication; “Letter to Melanchthon" (June 28, 1545), in CO 12:98-100.

${ }^{11}$ Commentary on Genesis 4:13; Comm. Harm. Law Numb. 3:5-10, 18-22, Deut. 5:19; Commentary on

Psalms Ps. 7:6-8; Lect. Jer. 22:1-3, 22:13-14; Lect. Ezek. 8:17; Comm. I Cor. 7:37.
} 
He also spoke frequently, as a student of Roman law would, about property rights: "the right to land," and other property, "the right to enjoy and use what one possesses," the "right to recover" and the "right to have restored" lost or stolen property; the "right to compensation" for work; the right "to sell," "to bequeath," and to "inherit" property, particularly in accordance with the "natural rights of primogeniture." He spoke of the "right to bury" one's parents or relatives. He also spoke frequently of the "marital" or "conjugal" rights of husband and wife, and the "sacred," "natural," and "common" "rights" of parents over their children - in particular, the "right" and "authority" of a father to "name his child," "to raise the child," and to set the child up in marriage. He spoke in passing about the "sacred right of hospitality" of the sojourner, the "right of asylum" or of "sanctuary" for those in flight, the "right of redemption" during the year of Jubilee, and the "natural rights" and "just rights" of the poor, the needy, the orphans, and the widows. ${ }^{12}$

Calvin gave an even fuller treatment of the moral or natural law and the respective roles of church and state in its elaboration and enforcement. Calvin described natural law as a set of moral commandments, written on the heart, repeated in the Scripture, and summarized in the Decalogue. God makes three uses of this natural law in governing humanity, said Calvin. First, God uses the moral law theologically - to condemn all persons in their conscience and to compel them to seek God's liberating grace. By setting forth a model and mirror of perfect righteousness, the moral law "warns, informs, convicts, and lastly condemns every man of his own unrighteousness." The moral law thereby punctures his vanity, diminishes his pride, and drives him to despair. Such despair, Calvin believed, is a necessary precondition for the sinner to seek God's help and to have faith in God's grace. Second, God uses the moral law civilly - to restrain the sinfulness of non-believers. "[T]he law is like a halter," Calvin wrote, "to check the raging and otherwise limitlessly ranging lusts of the flesh.... Hindered by fright or shame, sinners dare neither execute what they have conceived in their minds, nor openly breathe forth the rage of their lust." The moral law imposes upon them a "constrained and forced righteousness" or a "civil righteousness." Third, God uses the moral law educationally - to teach believers, those who have accepted his grace, the means and measures of sanctification, of spiritual development. Even the most devout saints, though free from the condemnation of the moral law, still need to follow the commandments "to learn more thoroughly ... the Lord's will [and] to be aroused to obedience." The law teaches them not only the "civil righteousness" that is common to all persons, but also the "spiritual righteousness" that is becoming of sanctified Christians. As a teacher, the law not only coerces them against violence and violation, but also cultivates in them charity and love. It not only punishes harmful acts

\footnotetext{
12 See RR, 57-59, 114-17.
} 
of murder, theft, and fornication, but also prohibits evil thoughts of hatred, covetousness, and lust. ${ }^{13}$

The moral law thus creates two tracks of norms - "civil norms" which are common to all persons and "spiritual norms" which are distinctly Christian. These two sets of norms, in turn, give rise to two tracks of morality - a simple "morality of duty" demanded of all persons regardless of their faith, and a higher "morality of aspiration" demanded of believers in reflection of their faith. ${ }^{14}$ This two-track system of morality corresponded roughly to the proper division of responsibility between church and state, as Calvin saw it in his later years. It was the church's responsibility to teach aspirational spiritual norms. It was the state's responsibility to enforce mandatory civil norms. This division of responsibility was reflected in the procedural divisions between the consistory and the council in Calvin's Geneva. In most cases that did not involve serious crimes, the consistory would first call parties to their higher spiritual duties, backing their recommendations with (threats of) spiritual discipline. If such spiritual counsel failed, the parties were referred to the city council to compel them, using civil and criminal sanctions, to honor at least their basic civil duties.

Calvin based this division of legal labor on the assumption that the church was a distinct legal entity with its own legal responsibilities in the local Christian commonwealth. This was a new emphasis in his later writings. God has vested in this church polity three forms of power (potestas), Calvin argued in his 1559 Institutes. The church holds "doctrinal power," the power to set forth its own confessions, creeds, catechisms, and other authoritative distillations of the Christian faith, and to expound them freely from the pulpit and the lectern. The church holds "legislative power," the power to promulgate for itself "a well-ordered constitution" that ensures "proper order and organization," "safety and security" in the church's administration of its affairs and proper decency" and "becoming dignity" in the church's worship, liturgy, and ritual. And, the church holds "jurisdictional power," the power to enforce positive laws that help to maintain moral and spiritual discipline in the community, particularly in matters of sex, marriage and family life, charity, poor relief, and education. ${ }^{15}$ The consistory was the institution that exercised this jurisdictional power of the church which complemented the city council, which exercised the jurisdictional power of the state.

Calvin's mature theory of the church combined ingeniously the principles of rule of law, democracy, and liberty. First, Calvin urged respect for the rule of law within the

\footnotetext{
13 John Calvin Institutes of the Christian Religion, [1559], ed. John T. McNeill, trans. Ford Lewis Battles (Philadelphia: Westminster Press, 1960) 2.7.6-12; 2.8.6, 51; 3.3.9; 3.6.1; 3.17.5-6; 3.19.3-6 (hereafter cited as Institutes (1559)). See also Commentary on Galatians 3.19, 5:13; Serm. Deut. 5:4-7; Comm. I Peter 1:14.

14 These phrases are from Lon L. Fuller, The Morality of Law, rev. ed. (New Haven: Yale University Press, 1964).

${ }^{15}$ Institutes (1559), 4.1.5; 4.8.1; 4.10.27-28; 4.11.1.
} 
church. He devised laws that defined the church's doctrines and disciplinary standards, the rights and duties of their officers and parishioners, the procedures for legislation and adjudication. The church was thereby protected from the intrusions of state law and the sinful vicissitudes of their members. Church officials were limited in their discretion. Parishioners understood their spiritual duties. When new rules were issued, they were discussed, promulgated, and well known. Issues that were ripe for review were resolved by proper tribunals. Parties that had cases to be heard exhausted their remedies at church law. To be sure, this principle of the rule of law within the church was an ideal that too often was breached, in Calvin's day and in succeeding generations. Yet this principle helped to guarantee order, organization, and orthodoxy within the Reformed church.

Second, Calvin urged respect for the democratic process within the church. Pastors, elders, teachers, and deacons were to be elected to their offices by communicant members of the congregation. Congregations periodically held collective meetings to assess the performance of their church officers, to discuss new initiatives within their bodies, to debate controversies that had arisen. Delegates to church synods and councils were to be elected by their peers. Council meetings were to be open to the public and to give standing to parishioners to press their claims. Implicit in this democratic process was a willingness to entertain changes in doctrine, liturgy, and polity, to accommodate new visions and insights, to spurn ideas and institutions whose utility and veracity were no longer tenable. To be sure, this principle did not always insulate the church from a belligerent dogmatism in Calvin's day or in the generations to follow. Yet this principle helped to guarantee constant reflection, renewal, and reform within the church.

Third, Calvin urged respect for liberty within the church. Christian believers were to be free to enter and leave the church, free to partake of the church's offices and services without fear of bodily coercion and persecution, free to assemble, worship, pray, and partake of the sacraments without fear of political reprisal, free to elect their religious officers, free to debate and deliberate matters of faith and discipline, free to pursue discretionary matters of faith, the adiaphora, without undue laws and structures. To be sure, this principle, too, was an ideal that Calvin and his followers compromised, particularly in their execution of Michael Servetus for heresy and blasphemy. Yet this principle helped to guarantee constant action, adherence, and agitation for reform by individual members of the church.

Calvin integrated these three cardinal principles into a new theory and practice of the church. Democratic processes prevented the rule-of-law principle from promoting an ossified and outmoded orthodoxy. The rule of law prevented the democratic principle from promoting a faith swayed by fleeting fashions and public opinions. Individual liberty kept both corporate rule and democratic principles from tyrannizing ecclesiastical minorities. Together, these principles allowed the church to strike a unique perpetual balance between law and liberty, structure and spirit, order and innovation, dogma and adiaphora. This delicate ecclesiastical machinery helped to 
render Calvinist churches remarkably adaptable and resilient over the centuries in numerous countries and cultures.

This integrated theory of the church had obvious implications for the theory of the state. Calvin hinted broadly in his writings that a similar combination of rule of law, democratic process, and individual liberty might serve the state equally well. Such a combination, he believed, would provide the best protection for the liberty of the church and its individual members. What Calvin adumbrated, his followers elaborated. In the course of the next two centuries, European and American Calvinists wove Calvin's core insights into the nature of corporate rule into a robust constitutional theory of the state which rested on the pillars of rule of law, democratic processes, and individual liberty.

\section{The Marian Exiles, Theodore Beza and the Right to Resist Tryanny}

While Calvin's views of rights and liberties, and church and state worked well enough for a small and largely homogenous city-state like Geneva they were harder to maintain in larger regions and nations with multiple faiths and authorities, some of whom became hostile to Calvinists. Calvin assumed that each local community would have a single faith. How could Calvinists countenance religious pluralism and demand toleration as a religious minority? Calvin assumed that church and state would cooperate in the governance of a godly polity. What if church and state came into collision, or even worse into collusion against Calvinists? Calvin assumed that Christian subjects should obey political authorities up to the limits of Christian conscience, and bear persecution with penitence, patience, and prayer in hopes that a better magistrate would come. But what if the persecution escalated to outright pogrom? Were prayer, flight, and martyrdom the only options for conscientious Christians? Was there no place for resistance and revolt, even regicide and revolution in extreme cases?

These challenges loomed ever larger after the 1540s as Calvinism spread rapidly into various parts of France, Germany, the Netherlands, England, and Scotland. Particularly the anti-Protestant persecution of Mary Tudor in England and Mary of Guise in Scotland in the early 1550s raised these questions acutely for local Calvinists, many of whom were killed or driven into exile on the Continent. Two of the most influential such "Marian exiles" to respond forcefully were John Knox and Christopher Goodman.

John Knox (c. 1514-1572), the fiery father of Scottish Presbyterianism, put Calvinist moderation and caution aside and argued for the Christian right and duty of organized resistance, revolt, and regicide against tyranny. Knox had been condemned to death as a heretic already in 1546 for his Protestant preaching. While he barely escaped execution, he spent two years as a prisoner rowing in the French galleys. This had hardened him in his resolve to fight against the religious tyranny of Catholic rulers. When the two Queen Marys began to reestablish Catholicism on the British Isles by the point of the sword, Knox insisted that his fellow Protestants must either flee or fight such tyranny and idolatry. To do nothing was to become an accomplice in the tyranny and to 
render oneself liable for the tyrant's idolatrous offenses against God. ${ }^{16}$ "For all those who would draw us from God (be they queens or kings), being of the devil's nature, are enemies unto God, and therefore will God [judge us] in such cases unless we declare ourselves enemies unto them." "We cannot keep the league between [God] and us inviolate if we favor, follow, or spare idolaters." ${ }^{17}$

When Knox came to Geneva in 1554, he asked Calvin "[w]hether it was necessary to obey a magistrate who enforces idolatry and condemns the true religion? And whether men of position who have castles and towns are entitled to defend themselves and their followers by armed force against this ungodly violence?"18 Calvin condoned flight, but not fighting. "If any tumult shall arise for the sake of religion," Calvin later reported on the conversation, "I pronounced that to me it seems the better and the safer course, to remain quiet till some peculiar call for interference should clearly appear - that it is our duty rather to ask God for a spirit of moderation and prudence, to stand us in aid in the critical moment, than to agitate idle inquiries."19

Knox soon rejected Calvin's calls for moderation - in his First Blast of the Trumpet Against the Monstrous Regiment of Women, and in a series of open letters to the queen, nobles, and common folk of Scotland, all published in Geneva in 1558. ${ }^{20}$ Knox wrote with vicious misogyny against the "unnatural rule," and "shameful gynaecrocy," of the two Queen Marys - arguments that ashamed Calvin, and alienated both Queen Mary Tudor and her successor Queen Elizabeth I against Calvinists. ${ }^{21}$ It was not so much Mary's gender, however, but her politics of reestablishing Catholic "idolatry" that moved Knox to call for her forceful removal, even her execution by lower magistrates or private persons. As he put it in a fateful passage: "I fear not to affirm that it had been the duty of the nobility, judges, rulers, and people, not only to have resisted and againststanded Mary, that Jezebel whom they call their Queen, but also to have her punished to the death with all sort of her idolatrous priests, together with all such as should have assisted her, what time that she and they openly began to suppress Christ's Evangel, to shed the blood of the saints of God, and to erect that most devilish idolatry ... which once most justly by common oath was banished from that realm."22

While Knox emphasized the people's divinely-ordained powers and prerogatives to depose their rulers even with violence, Christopher Goodman (1520-1603), the

\footnotetext{
16 John Knox, The Works of John Knox, ed. David Laing, 6 vols. (Edinburgh, 1846; repr. ed., New York: AMS Press, 1966), 2:453.

17 Ibid., 3:184, 187.

${ }^{18}$ Reported in letter of Bullinger to Calvin (March 26, 1554), CO 15:89-93; Calvin to Bullinger CO 15:123126.

${ }^{19}$ Letter to Bullinger, (April 28, 1554), CO 15:123-126.

${ }^{20}$ Knox, Works, 4:429-540.

${ }^{21}$ See Calvin, "Letter to William Cecil" (May, 1559), CO 17:490 disavowing Knox's misogyny.

${ }^{22}$ Knox, Works, 4:507.
} 
former Cambridge don exiled in Geneva, focused on the people's divinely-ordained rights and liberties. Goodman did include in his 1558 tract How Superior Powers Ought to be Obeyd some of the same misogynistic attacks on female rulers. And he did call for private resistance, even to the point of tyrannicide. ${ }^{23}$ But Goodman's more novel argument was that magistrates must strike a mean between granting their subjects "too much liberty" and "too little liberty." Granting too much liberty, he argued, will lead the people to contempt, sedition, "dissoluteness," "carnal liberty," rioting, tumult, and "contempt" for law and order "whether divine or human." But giving them too little liberty will do exactly the same. "[T]he people ought not suffer all power and liberty to be taken from them, and thereby to become brute beasts without judgment and reason, thinking all things lawful, which their rulers do without exception, command them, be they never so far from reason or godliness." God will "not suffer" that "the rights and liberties that he has given to all his people ... be taken from them." 24

What are "these rights and liberties that God has given to all his people" that cannot be "taken from them" - literally that cannot be "alienated"? They are the "inalienable" rights set out in the Bible, particularly in the Ten Commandments. As Goodman put it in a crucial passage:

[l]t is an easy matter for all manner of subjects to know what liberty belongs unto them by the word of God, which they may lawfully claim as their own possession, are likewise bound at all times to practice: wherein also appears what things are prohibited unto them, which they may in no case exercise.... $[T]$ here may be nothing lawful for you by any commandment of man, which your Lord God in any case forbids: and nothing unlawful or forbidden to you which he commands, whether it appertains to the first table or the second [table of the Decalogue]. Which rule if ye observe, you may be assured to please God: like as by doing the contrary you shall purchase his heavy wrath and indignation. ${ }^{25}$

This was Goodman's rights formula: The rights and liberties that God gives to each person as his or her "inalienable" "possession" are set out in the Decalogue. Nothing that God requires in the Decalogue may the magistrate forbid. Nothing that God forbids in the Decalogue may the magistrate require. A person thus has the inalienable right to "observe the Sabbath Day and keep it holy" and "to labor six days and to rest on the Sabbath." A person has the inalienable right to "honor [his or her]

${ }^{23}$ Christopher Goodman, How Superior Powers Ought to be Obeyd [1558], facs. ed., ed. Charles H. Mcllwain (New York, 1931), 52-53, 74-76, 97-99, 142 (spelling throughout modernized)..

24 Ibid., 147-154.

25 Ibid., 160-161. 
father and mother so that [their] days may be long in the land which the Lord your God has given [them]." A person has the inalienable right to proper religious worship and speech - to be free from laws commanding him to worship false gods, to maintain graven images, to swear false oaths, or otherwise take the name of God in vain. A person has the inalienable right to life (freedom from killing), to property (freedom from stealing), to marital integrity (freedom from adultery), and to reputation and fair process (freedom from false testimony). A person has the inalienable right to be free from having his family, household, and possessions coveted by others. If the magistrate requires or condones conduct contrary to this formula, the magistrate is violating each subject's rights and liberties. To do so is to practice tyranny and to invite resistance for God's sake. This was a considerably more expansive notion of liberties and rights than Calvin had countenanced to date.

Goodman referred in passing several times to this understanding of authority and liberty, rule and right as part of a "covenant" or "solemn agreement" made between the rulers and their subjects before God. These covenants, he suggested, were the modern parallels to the ancient biblical covenants in which Moses and the later kings of Israel promised to uphold the laws of God and the liberties of his people. In ancient times, breaches of these covenants by the rulers led to both divine censure and popular resistance. There were comparative lessons in this for our day, Goodman suggested. ${ }^{26}$ Though Goodman did not work out the political implications of these speculations about the political covenant and the inalienable rights that were guaranteed therein, they became the starting point for the mature political reflections of Calvin's hand-picked successor in Geneva, Theodore Beza (1519-1605), who was both a theologian and jurist like Calvin.

The catalyzing force for Beza's deep political reflections was the St. Bartholomew's Day Massacre of 1572, where up to 100,000 French Calvinists were slaughtered in a month of barbarism instigated by French Catholic authorities. Many thousands more were robbed and exiled or forced into re-communion with Rome. ${ }^{27}$ Building on the radical views of the Marian exiles, among others, Beza set out in in effect a Christian social and political contract theory. ${ }^{28}$ Every political government, Beza argued, is formed by a covenant or contract sworn between the rulers and their subjects before God who serves as both third party and judge. In this covenant, God agrees to protect and bless the community in return for their proper obedience of the laws of God

\footnotetext{
${ }^{26}$ Ibid., 72-75, 160, 164-165.

${ }^{27}$ Barbara Diefendorf, Beneath the Cross: Catholics and Huguenots in Sixteenth-Century Paris (New York: Oxford University Press, 1991); Janine Garrison-Estèbe, Tocsin pour un Massacre, la saison des Saint-Barthélemy (Paris: Le Centurion/Sciences humaines, 1968).

${ }^{28}$ See Théodore de Bèze, De lure Magistratum, translated as Concerning the Rights of Rulers Over Their Subjects and the Duties of Subjects Toward Their Rulers, trans. Henri-Louis Gonin (Cape Town: H.A.U.M.,1956) (hereafter cited as Rights of Rulers). See also Theodore Beza, Tractationum Theologicarum, 2nd ed., 3 vols. (Geneva: apvd Evstathivm Vignon, 1582) (hereafter cited as TT).
} 
and nature, particularly as set out in the Decalogue. The rulers agree to exercise God's political authority in the community, and to honor these higher laws and protect the people's rights. The people agree to exercise God's political will for the community by electing and petitioning their rulers and by honoring and obeying them so long as they remain faithful to the political covenant. If the people violate the terms of this political covenant and become criminals, Beza argued, God empowers rulers to prosecute and punish them - and sentence them to death in extreme cases. But if the rulers violate the terms of the political covenant and become tyrants, God empowers the people to resist and to remove them from office - and sentence them to death in extreme cases. The power to remove tyrants, however, lies not directly with the people, but with their representatives, the lower magistrates, who are constitutionally called to organize and direct the people in orderly resistance - in all out warfare and revolution if needed. ${ }^{29}$

For Beza, tyrants were rulers who violated the terms of the political covenant. particularly its foundational requirement that all must honor the natural law of God and the natural rights of the people. Going beyond Calvin, Beza made the rights of the people not just the happy consequence, but the necessary condition of good government. "The people are not made for rulers, but rulers for the people," he wrote. If the magistrate rules properly, the people must obey him. But if the magistrate abuses his authority in violation of the political covenant, the people, through their representatives, have the right and the duty to resist him as a tyrant. ${ }^{30}$

The issue that remained for Beza was how to ground his doctrine of rights and to determine which rights were so fundamental that, if pervasively and persistently breached by a tyrant, triggered the most basic right to organized resistance. Here Beza cleverly reworked Calvin's main arguments, taking his cues from Calvin's talk about the "natural rights" or "common rights of mankind," and the "the equal rights and liberties" of all persons. The first and most important rights, Beza reasoned, had to be religious rights - "liberty of conscience" and "free exercise of religion." Persons are, after all, first and foremost God's subjects and called to honor and worship God. If the magistrate breaches these religious rights, then nothing can be sacred and secure any longer. What is essential to the protection of the liberty of conscience and free exercise of religion, Beza continued catechistically: the ability to live in full conformity with the law of God. What is the law of God? First and foremost, it is the Decalogue which sets out the core duties of right Christian living. What do these Ten Commandments entail? They entail rights to worship God, to obey the Sabbath, to avoid foreign idols and false oaths in accordance with the First Table of the Decalogue, and the rights to marriage,

${ }^{29}$ Bèze, Rights of Rulers, 25, 27, 41-64, 73-85.

30 Ibid., 44-46, 64-66; Theodore Beza, Sermons sur l'histoire de la passion et sepulture de nostre Seigneur lesus Christ, descrite par les quatre Evangelistes (Geneva: apvd Evstathivm Vignon, 1592), $282,491,501$. For a discussion of marital and political divorce requiring orderly procedures, see Theodore Beza, De Repudiis et Divortiis (1569), in TT, 2:50-101 and SMF 2, chapters 9-13. 
parentage, and a household, and to life, property, and reputation protected by the Second Table. Is the Decalogue the only law of God?: No, the natural law that God has written on the hearts of all people teaches other rights that are essential to the protection of a person and a people. Beza touched on several of these broader natural rights: freedom of religious mission and education, freedom of church government and emigration, freedoms of speech, assembly, and petition, and freedom of marriage, divorce, and private contract. ${ }^{31}$

Beza did not fully ground and systematize these natural rights, nor did he make clear which of them was so fundamental that their breach could trigger organized resistance. But he put in place much of the logic of fundamental rights, constitutional order, and organized revolt that later Calvinists would refine and expand as they moved toward democratic revolution. In France, the most famous expansion of this argument came in the 1579 tract, Vindiciae Contra Tyrannos: Or Concerning the Legitimate Power of the Prince Over the People, and of the People Over the Prince, which even the eighteenth-century Jacobins would later cite with reverence. ${ }^{32}$ In Scotland, the most powerful exposition of Beza's ideas was George Buchanan's Dialogue on the Law of Kingship Among the Scots (1579/1601), which was used to justify the deposition of Mary Queen of Scots and which inspired many generations of later political Covenanters. ${ }^{33}$ In the Netherlands, Beza's ideas were axiomatic for the powerful Calvinist logic of revolution against Spanish tyranny that was set out in more than 10,000 pamphlets and sermons published from 1570-1610. ${ }^{34}$ The Dutch revolutionary writers were soon outdone by the 22,000 plus Calvinist tracts published in England from 1640-1660, written in defense of the Puritan revolution against the tyrannical King Charles and his ultimate execution by public beheading in $1649 .{ }^{35}$

This library of early modern Calvinist teachings on law, liberty, and authority deserves fuller attention by legal and political historians. In the space available here, let me focus on two of the most innovative contributors to this literature: Johannes Althusius (1557-1638) in the Netherlands, and John Milton (1608-1674) in England.

\footnotetext{
${ }^{31}$ Bèze, Rights of Rulers, 27-29, 44, 66, 68, 74, 80, 83-85; TT 2:120-121.

${ }^{32}$ Stephanus Junius Brutus, Vindiciae contra tyrannos: Concerning the Legitimate Power of a Prince over the People, trans. and ed., George Garnett (Cambridge: Cambridge University Press, 1994). For subsequent influences of natural rights, see Dale van Kley, The Religious Origins of the French Revolution: From Calvin to the Civil Constitution (New Haven: Yale University Press, 1996).

${ }^{33}$ George Buchanan, A Dialogue on the Law of Kingship among the Scots: A Critical Edition and Translation of George Buchanan's De lure Regni apud Scotos Dialogus, eds. Roger A. Mason and Martin S. Smith (Burlington: Ashgate, 2004); see also Caroline Erskine and Roger A. Mason, eds., George Buchanan: Political Thought in Early Modern Britain and Europe (Burlington: Ashgate, 2012).

${ }^{34}$ See Willem P.C. Knuttel, Catalogus van de pamflettenverzameling berustende in de Koninkje Bibliothek, 9 vols. (The Hague: Martinus Nijhoff, 1889-1920).

${ }^{35}$ See George Thomason, Catalogue of the Pamphlets, Books, Newspapers, and Manuscripts Relating to the Civil War, the Commonwealth, and Restoration, repr. ed. (Nendeln: Kraus Reprint, 1969); William Haller, Tracts in the Puritan Revolution, 1638-1647, 3 vols. (New York: Columbia University Press, 1934).
} 


\section{Johannes Althusius and Dutch Calvinism}

German-born jurist Johannes Althusius emerged both as an apologist for the Dutch revolt against the tyranny of Philip II and as an architect of a new Dutch legal and political order built thereafter. The Dutch Revolt followed a path strikingly similar to the American Revolution two centuries later. In the 1560s, Spanish emperor Philip II of Spain, who governed the Netherlands from afar, imposed a series of increasingly onerous restrictions on the Dutch people - heavy taxes, harsh commercial regulations, military conscriptions, forced quartering of soldiers, and more - all in violation of centuries-old charters of rights and liberties. Even worse, Philip set up the terrifying Spanish Inquisition in the Netherlands, slaughtering Calvinists and others by the hundreds and confiscating massive amounts of private property in a determined effort to root out Protestantism and implement the Catholic reforms of the Council of Trent. In the later 1560s and 1570s, the Dutch put into action the emerging Calvinist principles of resistance, throwing off their Spanish oppressors through revolutionary war. They issued a "declaration of independence" from Spain on the stated grounds of "clear truths" about "the laws and liberties of nature." They established a confederate government featuring seven sovereign provinces and a national government, each with its own constitution and its own bill of rights. ${ }^{36}$

These tumultuous political changes inspired much commentary, the most innovative of which came from Althusius, who lived in the Dutch city of Emden. Some of Althusius' work echoed and elaborated core political and legal teachings of Calvin, Beza, Knox, Goodman, and other Calvinists: the ideas that the republic is formed by a covenant between the rulers and the people before God, that the foundation of this covenant is the law of God and nature, that the Decalogue is the best expression of this higher law, that church and state are separate in form but conjoined in function, that families, churches, and states alike must protect the rights and liberties of the people, and that violations of these rights and liberties, or of the divine and natural laws that inform and empower them, are instances of tyranny that must trigger organized constitutional resistance.

Althusius added a number of other fundamental ideas to this Calvinist inheritance in his two masterworks: Politics (1603/14) and A Theory of Justice (1617/18). ${ }^{37} \mathrm{He}$ developed a comprehensive natural law theory that still treated the Decalogue as the

\footnotetext{
${ }^{36}$ E.H. Kossman and A. Mellink, eds., Texts Concerning the Revolt of the Netherlands (Cambridge: Cambridge University Press, 1974).

37 Johannes Althusius, Politica Methodice Digesta of Johannes Althusius (Althaus), ed. Carl J. Friedrich (Cambridge: Harvard University Press, 1932) (hereafter cited as Pol.); id., Dicaeologicae libri tres, totum et universum Jus, quo utimur, methodice complectentes (Frankfurt: Corvinus, 1618) (hereafter cited as Dic.).
} 
best source and summary of natural law but layered its Commandments with all manner of new biblical, classical, and Christian teachings. He developed a theory of positive law that judged the contemporary validity and utility of any human law, including the positive laws of Moses and the canon laws of the church, against both the natural law of Scripture and tradition and the fundamental law of the state. He called for a detailed written constitution as the fundamental law of the community and for perennial protection of the "rule of law" and "rule of rights" within church and state alike. $\mathrm{He}$ developed an expansive theory of popular sovereignty as an expression of the divine sovereignty that each person reflects as an image bearer of God. ${ }^{38}$

More original was Althusius's "symbiotic theory" of human nature and "covenantal theory" of society and politics. While acknowledging the traditional Calvinist teaching of the total depravity of persons, Althusius emphasized that God has created all persons as moral, loving, communicative, and social beings, whose lives are most completely fulfilled through symbiotic relationships with others in which they can appropriately share their bodies and souls, their lives and spirits, their belongings and rights. Thus, while persons are born free, equal, and individual, they are by nature and necessity inclined to form associations - marriages and families, clubs and corporations, cities and provinces, nation-states and empires. Each of these associations, from the tiniest household to the vastest empire, said Althusius, is formed by a mutually consensual covenant or contract sworn by all members of that association before each other and God. Each association is a locus of authority and liberty that binds both rulers and subjects to the terms of their founding contract and to the commands of the foundational laws of God and nature. Each association confirms and protects the sovereignty and identity of its constituent members as well as their natural rights and liberties. ${ }^{39}$

Althusius applied this Christian contract theory most fully in his description of the state. Using the political history of ancient Israel as his best example, he showed historically and philosophically how nation-states develop gradually from families to tribes to cities to provinces to nations to empires. Each new layer of political sovereignty is formed by covenants sworn before God by representatives of the smaller units, and these covenants eventually become the written constitutions of the polity. The constitutions define and divide the executive, legislative, and judicial offices within that polity, and govern the relations of its rulers and subjects, clerics and magistrates, associations and individuals. They determine the relations between and among nations, provinces, and cities, and between and among private and public associationsall of which Althusius called a form of "federalism" (from "foedus," Latin for covenant). The constitutions also make clear the political acts and omissions that constitute tyranny and the procedures and remedies available to those who are abused.

\footnotetext{
${ }^{38}$ For an expansion of this discussion and its accompanying sources, see RR, 156-69.

39 Ibid., 181-202.
} 
Althusius also developed a detailed and refined theory of natural rights based on the Decalogue, which he viewed as the best source and summary of the natural law. Using the two tables of the Decalogue, he divided these natural rights into (1) spiritual or religious rights and liberties (iura et libertates religionis) or "rights of the soul and mind" (iura animae); and (2) temporal or civil rights and liberties (iura et libertates civile) or "rights of society" (iura societatis). Althusius regarded both these sets of natural rights as "fundamental rights" - indispensable to the survival of a person and polity and foundational to any more specific rights formulations at positive law.

In expounding religious rights, Althusius defended the absolute liberty of conscience, which he saw as the natural corollary to the absolute sovereignty of God, a doctrinal staple of Calvinism. Sovereignty is a legal term, said Althusius, a right and power to command and control. Through the opening words of the Decalogue, "I am the Lord, thy God," the Bible makes clear that "God alone can command the conscience." God alone can bring a person "out of the house of sinful bondage" and into the "promised land" - whether in this life or in the next. God alone can change the hearts and charge the souls of men. No human person or authority may thus require a person "to believe against his will. Faith must be persuaded, not commanded; it must be taught, not ordered." For the magistrate or anyone else to invade the sanctuary of conscience is to impugn the sovereignty of God. For the magistrate "to impose a penalty on the thoughts of men" is to obstruct the work of the Holy Spirit. "The natural law imparts to all men a freedom of the soul or mind (libertas animi)," Althusius wrote in later summary of his position. "This is an unfettered power to want and to choose...to evaluate, to desire, and to make choices," which cannot "be hindered by a command or order, by fear or compulsion." 40

While all parties must enjoy absolute freedom of conscience lest the sovereignty of God be invaded, no one can enjoy absolute "freedom of religious exercise" lest the integrity of society be compromised. The ideal is that all will see the same divine light and come to the "one true orthodox Christian religion" - by which Althusius meant Calvinism. But, given human sinfulness, no such religious uniformity has ever existed in history, or could be hoped for today. Individual households and congregations, sometimes even small villages and towns may practice a uniform faith, but this uniformity rarely exists beyond the local level. At the provincial, national, and imperial levels, religious pluralism is inevitable. Althusius thus counseled toleration of Protestants, Jews, Catholics, and even peaceable "atheists" and "heretics" in the community. ${ }^{41}$

40 Althusius, Pol. VII.4-7; Pol. XI.33-45; Pol. XXVIII.14, 37-73, 62-66; Dic. I.25.8-10.

${ }^{41}$ Althusius, Pol. IX.41-45; Pol. XXVIII.56-58, 68-72; Pol. XXX.1-6; Pol. XXXI.1-6; Dic. I.101.20-35; Dic.

1.115.10-36. 
Though he put more limits on their religious freedom than we would find acceptable today, his views were more progressive than many in his day. It is an instructive anecdote that John Locke's famous Letter on Toleration of 1689, much of it drafted while Locke sat in the liberal Dutch coffee houses, was considerably more restrictive than Althusius's Politics published 75 years earlier. For Locke, Catholics, Muslims, and other believers "who deliver themselves up to the service and protection of another prince" have no place in the community. Jews hardly figured in his toleration scheme, and "those are not at all tolerated who deny the being of a God"-for "promises, covenants, and oaths which are the bonds of human society, can have no hold upon an atheist." 42

While the First Table of the Decalogue anchored each person's religious rights, Althusius continued, the Second Table anchored each person's natural social rights and correlative natural duties. First, everyone has the right to "natural life" and "bodily liberty and protection." This include the freedom to nourish, protect, and care for one's own life and limb, the right to carry arms for protection, the right to proportionate defense of oneself and one's possessions that are needed for life, freedom from murder, assault, and personal injury, and freedom from unjust punishment, imprisonment, repression, or detainment. The commandment "thou shalt not kill" imposes the corresponding duties on everyone not to "hurt, strike, or treat his body in any inhumane way," or to "diminish or take away the use of his body." And, among family members this commandment imposes on each the duty to protect and care for their parents, siblings, children, as well as their kin if they are able.

Second, everyone has the "right to purity and chastity" (ius castitus et pudicitia) the right to keep oneself holy, chaste, and pure in mind and body, and to restrict and resist the actions of others who threaten or violate the same. The commandments against adultery and coveting one's neighbor impose the corresponding duties on all to desist from fornication and lust, and to deal with their neighbor "free from the passion of our concupiscence and perverse desire."

Third, everyone has the right to property (ius dominium), to the "fruit of his labors," and "to goods that he uses and enjoys." The commandment against stealing requires others to respect and conserve a neighbor's "title, possession, and use" of his or her property and not to injure, diminish, or remove these property interests.

Fourth, everyone has the right to a good reputation - the right to enjoy the "honor," "good name," "standing, excellence, dignity, fame, authority, esteem, and prominence" that become his or her status and station in society as accorded by nature,

42 John Locke, Letter Concerning Toleration (1689), in The Works of John Locke, 12th ed., 9 vols. (London: Rivington,1824), 5:47. See also John Perry, The Pretenses of Loyalty: John Locke, Liberal Theory, and American Political Theology (New York: Oxford University Press, 2011). 
custom, law, and circumstance. Althusius called this bundle of reputation rights a person's "second self," his "civil personality." A person's honor, word, and integrity were vital to their social survival and flourishing. The commandment "thou shalt not bear false witness" imposes the corresponding duty on everyone to protect the reputation and good name of their neighbors and desist from insults, lies, defamation, and slander.

Fifth, everyone has the "right to a family" (ius familiae) - the right to marry, to procreate, nurture, and educate their children, to have their marriage, family, and household respected and protected. The commandments about honoring parents, not committing adultery, and not coveting a neighbor's wife or maidservant, in turn, impose on everyone else the duty to respect the "honor, authority, dignity, and preeminence, and indeed the right of the family." 43

These five basic natural rights of social life, anchored in the Second Table of the Decalogue, undergirded a full system of public, private, penal, and procedural rights that were to be "constituted" by the positive law of the state. Althusius expounded on each of these collections of rights at great length. ${ }^{44}$ By the time he was finished, he had defined and defended almost every one of the rights that would appear in the American federal and state constitutions a century and a half later.

\section{John Milton and English Calvinism}

While Johannes Althusius grounded his theory of rights and liberties in the Decalogue, English poet and philosopher John Milton based his theory of rights on the biblical trope that each person is called to be a prophet, priest, and king. Like Beza and Althusius, Milton wrote in the midst of revolution - this time against the English Stuart kings, James I and Charles I, who were imposing oppressive royal taxes and fees, harsh new Anglican establishment laws and persecution, and untold abuses of the royal and ecclesiastical courts. When the English Parliament was finally called into session in 1640, after an eleven-year hiatus, it leaders seized power by force of arms. Civil war erupted between the supporters of Parliament and the supporters of the King. The Parliamentary party, dominated by Calvinists, eventually prevailed and passed an act in 1649 "declaring and constituting the People of England to be a Commonwealth and Free State." Parliament abolished the kingship, and, remarkably, King Charles was tried by a special tribunal, convicted for treason, and beheaded in public. Parliament also abolished the aristocratic House of Lords and declared that "supreme authority" resided in the people and their representatives. Anglicanism was formally disestablished, and episcopal structures were replaced with Calvinist church forms. "Equal and proportional representation" were guaranteed in the election of local

\footnotetext{
${ }^{43}$ Althusius, Dic. I.25-26; Dic. I.117-122; Pol. X.5-7.

${ }^{44}$ Althusius, Dic. 1.5, 7-10, 18-33, 36-63, 78-81,130; Dic. II.12-23; Dic. III.9.38-44; Pol. III.37-41.
} 
representatives to Parliament. England was now to be under "the democratic rule" of Parliament and the Protectorate of the Calvinist military leader, Oliver Cromwell. ${ }^{45}$

After Cromwell died in 1658, however, the Commonwealth government collapsed. King Charles II, son of Charles I, returned to England, reclaimed the throne in 1660, and restored traditional monarchical government, Anglican establishment, and pre-revolutionary law. This Restoration era was short-lived, however. When his successor King James II, the other son of Charles I, began to abuse his royal prerogatives as his father had done, Parliament forced him to abdicate the throne in 1688 in favor of the new dynasty of William and Mary. This was the Glorious Revolution. It established permanently government by the King in Parliament and introduced a host of new guarantees to English subjects, notably those set out in the Bill of Rights and the Toleration Act of 1689.

The English Revolution unleashed a massive torrent of writings and legislation by Calvinist reformers calling for the reformation of English law and the enforcement of the rights and liberties of Englishmen. Part of the effort was to extend the traditional rights of life, liberty, and property in the Magna Carta (1215) to apply to all churches and citizens, not just Anglicans and aristocratic freemen. Part of the effort was to build on the Petition of Right (1628), a Parliament document that had set out several public, private, and procedural rights for the people and their representatives in Parliament. But the most radical and memorable efforts of the English Revolution were the many petitions and platforms issued in the 1640s and 1650s calling for the establishment of a democratic government dedicated to protection of a full panoply of rights and liberties of the people. These included freedoms of religion, speech, press, and assembly; the right to conscientious objection to oaths, tithes, and military service; freedom from forced quartering of soldiers and sailors; freedom of private property and from unjust takings; freedom from excessive taxation and regulation; freedom of private contract, inheritance, marriage, and divorce; the right to civil and criminal jury trial; and all manner of criminal procedural protections - no ex post facto legislation and bills of attainder, no warrantless arrests, no illegal searches and seizures, the right to bail, the right to a fair and speedy trial, the right to face one's accusers, the right to representation in court, the privilege against self-incrimination, freedom from cruel investigation and punishment, the right to appeal. While most of these rights proposals were quashed - partly by Cromwell's Protectorate and altogether by the Restoration government of 1660 - they provided a normative totem for the later common law to make real. Already in the Glorious Revolution of 1689 , freedoms of religion, speech, and assembly were partly realized, as were several criminal procedure protections. And, many more of these rights proposals came to vivid expression and experimentation in the English colonists

\footnotetext{
${ }^{45}$ See RR, 209-220; Harold J. Berman, Law and Revolution II: The Impact of the Protestant Reformations on the Western Legal Tradition (Cambridge: Harvard University Press, 2006).
} 
in North America. ${ }^{46}$

John Milton wrote brilliantly and abundantly in support of these voluminous new rights claims and the attendant constitutional orders designed to protect them. Drawing on Calvin and others, Milton argued that each person is created in the image of God with "a perennial craving" to love God, neighbor, and self. Each person has the law of God written on his and her heart, mind, and conscience, and rewritten in Scripture, most notably in the Decalogue. Each person is a fallen and fallible creature in perpetual need of divine grace and forgiveness which is given freely to all who ask for it. Each person is a communal creature, naturally inclined to form private, domestic, ecclesiastical, and political associations. Each such association is created by a consensual covenant or contract that defines its form and function and the rights and powers of its members, all subject to the limits of natural law. Each association is headed by an authority who rules for the sake of his subjects and who must be resisted if he becomes abusive or tyrannical. All such resistance must be as moderate, orderly, and peaceable as possible, but it may rise to revolt and regicide if necessary in the political sphere. All this was by now standard lore in Calvinist circles. ${ }^{47}$

In devising his own reformation of rights, Milton seized on what he thought to be the Calvinist reformers' most important lesson; namely, that the Reformation must always go on - semper reformanda. England must not idolize or idealize any Protestant teachings, Milton insisted, even those of Calvin and the Genevan fathers. England must rather develop and deepen, apply and amend these teachings in a continuous effort to reform church, state, and society anew. Milton further seized on what he took as a cardinal teaching of Calvinism - that God calls each and every person to be a "prophet, priest, and king," and vests each person with natural rights and duties to speak, worship, and rule in church and state, family and society at once. For Milton, the driving forces of England's perpetual reformation, therefore, were not only clerics or magistrates, scholars or aristocrats. The true reformers were just as much the commoners and householders, craftsmen and farmers of every peaceable type. Every person was created by God with the freedom of conscience, reason, and will. Every person was called by God to discharge both their private Christian vocations and their public social responsibilities in expression of their love of God, neighbor, and self. This was a form of Christian populism and popular sovereignty that the Calvinist tradition had not put quite so strongly before. ${ }^{48}$

\footnotetext{
${ }^{46}$ See the chapter by David Little.

${ }^{47}$ See Don M. Wolfe ed., Complete Prose Works of John Milton, 7 vols. (New Haven: Yale University Press, 1953-1980), 7:340-463.

${ }^{48}$ See John Witte, Jr., "Prophets, Priests, and Kings of Liberty: John Milton and the Reformation of Rights and Liberties in England," Emory Law Journal 57 (2008): 1527-1604.
} 
Milton went even further beyond traditional Calvinist teachings in defining the religious, domestic, and civil rights and liberties that each person must enjoy in discharging these offices of prophet, priest, and king. Among religious liberties, he defended liberty of conscience, freedom of religious exercise, worship, association, and publication, equality of multiple biblical faiths before the law, separation of church and state, and disestablishment of a national religion - ideas which would become axiomatic for Roger Williams and other later American religious freedom advocates. ${ }^{49}$ Among domestic liberties, he stressed urgently the right to marry and divorce in accordance with the explicit teachings of Scripture alone as well as attendant rights to nurture, discipline, and educate one's children and to have one's private home free from unwanted searches and seizures of papers and possessions. ${ }^{50}$ Among civil liberties, he offered a brilliant defense of the freedoms of speech and press, which ultimately proved pivotal for the abolition of censorship and licensing rules at common law. He also defended earnestly the rights to democratic election, representation, petition, and dissent, as well as the rights to private contract and association and to jury trial. All these rights arguments were echoed in hundreds of Calvinist pamphlets, sermons, and learned treatises on both sides of the Atlantic, and would become commonplaces among constitutional reformers in the eighteenth and nineteenth centuries. ${ }^{51}$

\section{Final Reflections}

In his magisterial history of rights in the Roman Catholic tradition, Brian Tierney writes: "Nowadays it has become fashionable to maintain, as Pope John Paul II recently asserted, that religious rights are the 'cornerstone' of all other rights. But, viewed in historical perspective, religious rights came last; these rights were the most difficult to conceive of, let alone put into practice." 52 Tierney has shown better than anyone that all manner of subjective rights and liberties were created already by medieval Catholic canonists and theologians, and that these rights were further expanded and refined by early modern Spanish and Portuguese Catholic philosophers and moralists. But it was only in the Second Vatican Council's great Declaration of Religious Freedom (Dignitatis Humanae) of 1965 , Tierney writes, that the Catholic Church came to embrace fully the doctrine of religious rights for individuals and groups, and to rework its vast rights structures with religious rights at their foundation.

The exact opposite pattern of development prevails in the history of Calvinism. In the Calvinist tradition, religious rights came first, for they were the easiest for

\footnotetext{
${ }^{49}$ See RR, 226-48.

50 lbid., 248-59.

51 Ibid., 259-71.

52 Brian Tierney, "Religious Rights in Historical Perspective," in Religious Human Rights in Global Perspective: Religious Perspectives, eds., John Witte, Jr. and Johan D. van der Vyver (The Hague: Martinus Nijhoff, 1996), 1-31, at 17-18. See also Brian Tierney, The Idea of Natural Rights: Studies on Natural Rights, Natural Law, and Church Law, 1150-1625 (Grand Rapids: Wm. B. Eerdmans, 1996).
} 
persecuted Calvinists to conceive; other rights developed gradually and sporadcally over the next centuries, and with varying intellectual foundations and institutional force. From the start, religious rights were the cornerstones of Calvinist rights theories freedom of conscience, freedom of exercise, and freedom of the church. Only over time did early modern Calvinists develop systematically the attendant individual freedoms of speech, press, and assembly, rights to petition, dissent, and revolt, rights to marry, divorce, and associate, rights to evangelize, educate, and parent, rights to emigrate, travel, and evangelize, and more. Only over time did they develop corporate rights to chapels, schools, and charities, freedoms of doctrine, liturgy, and worship, rights to catechize, educate, and discipline, freedoms of press, contract, and association. Only over time did they begin to press more generically for various rights to life, liberty, and property, due process and equal protection, and sundry civil and criminal procedural rights. But historically, and to this day, Calvinists stumbled in ways that medieval and modern Catholics never did on the protection of various social, economic, and cultural rights.

Among the most important catalysts of rights development in early modern Calvinism were the bloody massacres of Calvinists in France and the Netherlands, the severe persecution of Calvinists in Scotland and England, the open wilderness that faced New England Puritans, and the new constitutions demanded by the American Revolution. Calvinists responded to these challenges both with sharp swords and with strong words. Out of the hot pamphlets and fiery sermons issued in the heat of revolutionary battle and in justification of their violence, came more systematic tracts and treatises a generation or two later that furnished enduring lessons for the Calvinist tradition, and for the broader Western tradition as well.

Many of these enduring lessons about rights and liberties eventually gravitated toward familiar doctrinal heads of Calvinist theology. The first rights of religion, for example, fell neatly under the first doctrine of Calvinism, namely, the doctrine of God. The religious rights of the individual are in part temporal expressions of what Calvin already called the "eternal rights of God." These are the rights of God the Father, who created humans in his own image and commanded them to worship him properly and to obey his Commandments fully. They are the rights of God the Son, who embodied himself in the church and demanded the free and full exercise of this body upon earth. And they are the rights of God the Holy Spirit, who is "poured out upon all flesh" and governs the consciences of all persons in their pursuit of happiness and holiness.

Religious rights are in no small part the right of persons to do their duties as image bearers of the Father, as prophets, priests, and kings of Christ, and as agents, apostles, and ambassadors of the Holy Spirit. As image bearers of God, persons are given natural law, reason, and will to operate as responsible creatures with choices and accountability. They are given the natural duty and right to reflect God's glory and majesty in the world, to represent God's sovereign interests in church, state, and society alike. As prophets, priests, and kings of God, persons have the spiritual duty and right to speak and to prophesy, to worship and to pastor, to rule and to govern on God's behalf. As apostles and ambassadors of God, persons have the Christian duty and 
right to "make disciples of all nations" by word and sacrament, by instruction and example, by charity and discipline.

The doctrine of sin also influenced early modern Calvinists' insights into the nature of rights and their constitutional protection. It was their doctrine of sin that led Calvinists from the start to emphasize the need both for individual discipline and for structural safeguards on offices of authority. Individual discipline came in part through regular catechesis and education, through regular corporate worship and communal living. But the foundation of individual discipline was the law of God and nature, particularly as distilled in the Ten Commandments. Its two tables prescribed the duties of love that a disciplined believer owed to God and to neighbors respectively.

Within a generation after Calvin, his followers had flipped these Decalogue duties into Decalogue-based rights. Nothing that God requires in the Decalogue may the magistrate forbid, they argued. Nothing that God forbids in the Decalogue may the magistrate require. A person thus has the right to "observe the Sabbath Day and keep it holy" and "to labor six days and to rest on the Sabbath." A person has the right to "honor [his or her] father and mother so that [their] days may be long in the land which the Lord your God has given [them]." A person has the right to proper religious worship and speech - to be free from laws commanding them to worship false gods, to maintain graven images, to swear false oaths, or otherwise take the name of God in vain. A person has the right to life (freedom from killing), to property (freedom from stealing), to marital integrity (freedom from adultery), and to reputation and fair process (freedom from false testimony). A person has the right to be free from having his or her family, household, and possessions coveted by others. If the magistrate requires or condones conduct contrary to this divine formula, the magistrate is violating each subject's fundamental rights and liberties. To do so is to practice tyranny and to invite resistance and revolt.

The doctrine of sin also led Calvinists to emphasize strongly the need for constitutional safeguards on authorities within church and state. While the offices of church and state were ordained by God and represent God's authority on earth, the officers who occupy these offices are sinful human creatures. Calvinists thus worked hard to ensure that these offices were not converted into instruments of self-gain and self-promotion. By the later seventeenth century, Calvinists on both sides of the Atlantic came to emphasize the need for popular election of ministers and magistrates, limited tenures and rotations of ecclesiastical and political office, separation of church and state, separation of powers within church and state, checks and balances between and amongst each of these powers, federalist layers of authority with shared and severable sovereignty, open meetings in congregations and towns, codified canons and laws, transparent proceedings and records within consistories, courts, and councils. All these safeguards and more were designed to protect the offices of church and state from their own officers, but even more to protect the rights and liberties of parishioners and citizens who were subject to these authorities. It was through the doctrine of covenants, modeled in part on the biblical covenants of ancient Israel, that early modern Calvinists were able to constitutionalize these many safeguards. 